\title{
Optimization of bioactive isorhamnetin 3-O-glucoside production in Escherichia coli
}

\author{
Bong-Gyu Kim ${ }^{1}$ iD
}

\section{대장균에서 isorhamnetin 3-O-glucoside의 생합성 최적화}

김봉규 ${ }^{1}$

Received: 7 October 2019 / Accepted: 21 October 2019 / Published Online: 31 December 2019

(C) The Korean Society for Applied Biological Chemistry 2019

\begin{abstract}
Isorhamnetin 3-O-glucoside, a member of the flavonol group, has been reported to be effective for inflammatory and ulcer, as well as to alleviate diabetic complications such as neuropathy, nephropathy and retinopathy. Isorhamnetin 3-Oglucoside has been extracted from several plants. Biotransformation is a valuable tool, which is used to produce value-added chemicals with inexpensive compounds. To synthesis isorhamnetin 3-Oglucoside from quercetin, two genes (PGT E82L and ROMT-9) were introduced into Escherichia coli, respectively. In order to synthesis isorhamnetin 3-O-glucoside from quercetin, a co-culture fermentation system was developed by optimizing the medium and temperature for biotransformation, the cell mix ratio, Isopropyl- $\beta$-D-thiogalactoside induction time, and quercetin feed concentration. Finally, isorhamnetin 3-O-glucoside was biosynthesized up to $181.2 \mathrm{mg} / \mathrm{L}$ under the optimized biotransformation condition, which was higher 4.7 times than previously reported $(39.6 \mathrm{mg} / \mathrm{L})$.
\end{abstract}

Keywords Biotransformation - Co-culture $\cdot$ Flavonoids $\cdot O$ Methyltransferase · UDP-glycosyltransferase

Bong-Gyu Kim $(\bowtie)$

E-mail:dkimbk@gntech.ac.kr

${ }^{1}$ Department of Forest Resources, Gyeongnam National University of Science and Technology, 33 Dongjin-ro, Jinju-si, Gyeongsangnam-do, Jinju 52725, Republic of Korea

This is an Open Access article distributed under the terms of the Creative Commons Attribution Non-Commercial License (http://creativecommons. org/licenses/by-nc/3.0/) which permits unrestricted non-commercial use, distribution, and reproduction in any medium, provided the original work is properly cited.

\section{서 론}

플라보노이드는 C6-C3-C6 기본골격을 가진 화합물을 통칭하는 파이토케미컬로서 페닐프로파노이드 생합성경로를 통해서 합성 된다[1]. 나린제닌은 다양한 플라보노이드 합성의 전구체로 사 용되는 물질로 $p$-coumaroyl-CoA 한분자와 malonyl-CoA 세분 자가 chalcone synthase와 chalcone isomerase의 연속적인 반응 으로 합성된다[2]. 플라보노이드는 $\mathrm{C}$ 링의 이중결합, 산화, 수산 화기의 차이, $\mathrm{B}$ 링과 $\mathrm{C}$ 링의 연결 위치의 차이에 따라 flavones, flavanones, flavonols, flavan-3-ols, isoflavones, anthocyanidins 등과 같이 6개의 그룹으로 분류한다[3]. 플라보노이드는 6가지 기본골격을 바탕으로 methylation, hydroxylation, prenylation, glycosylation 등을 통하여 다양한 유도체들로 합성되며, 지금까 지 약 9,000 여 종 이상이 자연계에서 발견된다[4]. 이들 중 glycosylation과 methylation은 플라보노이드 구조변형에 많은 역 할을 담당하고 있다[5,6].

플라보노이드는 식물 뿐만 아니라 동물에도 다양한 생리학적 역할을 한다. 플라보노이드는 병원성 곰팡이나 박테리아의 공격 으로부터 식물을 보호할 뿐만 아니라 자외선과 같은 비생물학 적 요소에 대한 저항성에도 관여한다[7]. 또한, 식물 광합성에 있어 전자전달 및 식물호르몬의 이동에도 영향을 미친다. 사람 에 있어 플라보노이드는 폐암, 류마티스관절염, 항바이러스, 심 장병, 당뇨병, 뇌졸중, 천식, 백내장 등과 같은 다양한 질환에 효과를 보인다[8]. 일반적으로 사람이 섭취하는 플라보노이드 대 부분은 야채와 과일 등으로부터 공급하지만, 때로는 커피, 와인, 녹차 등과 같이 식물로부터 추출을 통해 섭취하기도 한다[9]. 플라보노이드는 알칼로이드나 터페노이드 등과 달리 약한 독성 을 보이기 때문에 이를 이용한 화장품 및 식 - 의약 소재를 개 발하기 위한 다양한 연구들이 이루어지고 있다[9-12]. 하지만, 이들 물질의 공급은 대부분 식물로부터 직접 추출하거나 화학 적 합성법으로 이루어졌다. 플라보노이드의 화학적 합성법은 촉 
매제로 독성물질이 사용되고, 합성과정과 분리정제과정이 복잡 한 어려운 면을 가지고 있다[13]. 현재, 플라보노이드의 대부분 은 식물에서 추출하여 사용하고 있다. 하지만, 식물에 존재하는 플라보노이드의 함량이 낮고 복잡한 분리 - 정제과정을 필요로 하며, 식물을 재배하기 위한 공간적 시간적 제약이 따르는 어 려운 점이 있다[14,15]. 따라서, 플라보노이드의 다양한 생리활 성에도 불구하고 이들의 안정적인 공급에는 많은 어려움을 가 지고 있다. 최근 이러한 문제를 극복하기 위해 식물세포 뿐만 아니라 효모, 바실러스, 스트렙토마이세스, 대장균 등과 같은 미 생물을 이용한 플라보노이드의 대체생산법 등이 개발되고 있 다. 특히, 대장균은 배양과 형질전환이 쉬울 뿐만 아니라 대장 균 내의 생합성과정이 잘 알려져 있고 대사 조절이 가능하기 때문에 플라보노이드 생산 균주로 많이 이용한다[16-18].

Isorhamnetin 3-O-glucoside는 flavonol그룹에 속하는 화합물 로 항염, 항궤양 효과 및 aldose reductase 저해제로 작용하여 신경장해, 신장병증, 망막증과 같은 당뇨합병증의 치료에 효과 가 있는 것으로 알려져 있다[19,20]. 다양한 생리적 활성에도 불 구하고 isorhamnetin 3-O-glucoside는 Tetraena aegyptia, Salsola oppositifolia, Salicornia herbacea, Sambucus ebulus와 같은 식 물로부터 추출하여 사용하기 때문에 이물질을 안정적으로 공급 하기 어려운 면이 있다[19,20]. 따라서, isorhamnetin 3-Oglucoside를 안정적으로 공급할 수 있는 대체생산법이 개발법이 필요하며, 이를 바탕으로 isorhamnetin 3-O-glucoside의 또 다른 생리활성을 탐색하는 데 사용 가능할 것이다.

본 연구에서는 Populus deltoides에서 분리한 flavonol UDPglycosyltransferase (PGT-3)의 82번 아미노산을 glutamate에서 Leucine으로 치환한 돌연변이체(PGT-3 Glu82Leu)와 벼에서 분 리한 $O$-methyltransferasse-9 (ROMT-9)을 대장균에 도입하여 quercetin 으로부터 isorhamnetin 3-O-glucoside를 생산하는 방법 을 최적화하였다.

\section{재료 및 방법}

\section{대장균 균주, 벡터 및 배양 배지}

Escherichia coli $\mathrm{DH} 5 \alpha$ 균주는 유전자 클로닝 및 플라스미드를 증폭에 사용하였다. E. coli BL21 (DE3) 균주는 isorhamnetin 3-O-glucoside 생산을 위한 생물전환 호스트로 사용하였다. pGEX 5X-3벡터는 PGT-3 E82L 또는 ROMT-9 클로닝에 사용 하였다. Andrw's Magic Media (AAM) [21]와 Difco사의 LB, $\mathrm{M} 9, \mathrm{YPD}, \mathrm{TB}$ 배지는 대장균 배양 및 생물전환용 배지로 사용 하였다. 배지내 탄소원은 다른 언급이 없으면 글리세롤을 $20 \mathrm{~g} / \mathrm{L}$ 의 농도로 첨가하였다. Quercetin은 sigma사로부터, isorhamnetin, isorhamnetin 3-O-glucoside는 INDOFINE사로부터 구매하였다.

\section{생물전환}

PGT-3 E82L 또는 ROMT-9을 담고 있는 각각의 대장균 단일콜 로니를 ampicillin $(100 \mu \mathrm{g} / \mathrm{L})$ 을 담고 있는 $2 \mathrm{~mL} \mathrm{LB}$ 액체 배지 에 접종하여 $37^{\circ} \mathrm{C}$ 배양기에서 $200 \mathrm{rpm}$ 의 조건으로 밤새도록 배양하였다. 다음날 각각 $250 \mathrm{~mL}$ 플라스크에 ampicillin (100 $\mu \mathrm{g} / \mathrm{L}$ )이 첨가된 $25 \mathrm{~mL}$ 의 새로운 $\mathrm{LB}$ 에 전날 배양액 $250 \mu \mathrm{L}$ 를 접종하여 $37^{\circ} \mathrm{C}$ 인큐베이터에서 배양하였으며, 세포 밀도가
OD600 nm에서 0.6이 되었을 때 Isopropyl $\beta$-D-1-thiogalactopyranoside (IPTG)의 최종농도가 $0.1 \mathrm{mM}$ 이 되게 첨가하였다. 그 후 플라스 크를 $25^{\circ} \mathrm{C}$ 인큐베이터로 옮겨 24 시간 동안 재조합 단백질을 유도하였다. 각각의 대장균 세포는 원심분리기를 이용하여 회수 하고 $10 \mathrm{~mL}$ AAM 배지로 간단히 씻고, ampicillin $(100 \mu \mathrm{g} / \mathrm{L})$, $0.1 \mathrm{mM}$ IPTG, quercetin $200 \mathrm{M}$ 을 첨가한 $\mathrm{AAM}$ 배지 $25 \mathrm{~mL}$ 에 각각의 세포 밀도가 2.0 이 되게 현탁 하여 $30{ }^{\circ} \mathrm{C}$ 에서 생물전환 을 하였다. 반응물은 배양 12 시간 후 배양액 $500 \mu \mathrm{L}$ 를 회수하 여 동량의 에틸아세테이트를 첨가하여 2회 반복 추출하여 진공 건조기로 완전히 건조하였다. 건조한 반응 산물은 Dimethyl sulfoxide (DMSO)에 녹여 Varian high performance liquid chromatography (HPLC) 분석에 사용하였다.

\section{HPLC분석}

생물전환으로 얻은 반응물은 분석은 HPLC 시스템(Agilent Technologies, Santa Clara, CA, USA)을 이용하였다. 반응물의 분리와 검출은 Polaris $5 \mathrm{C} 18-\mathrm{A}$ column $(250 \mathrm{~mm} \times 4.6 \mathrm{~mm}$, Agilent Technologies)과 photodiode array를 이용하였다. HPLC 분석은 $\mathrm{A}$ 버퍼 $(0.1 \%$ formic acid가 첨가된 3차 증류수)와, $\mathrm{B}$ 버 퍼 $(0.1 \%$ formic acid가 첨가된 acetonitrile)를 사용하였다. $\mathrm{HPLC}$ 분석프로그램은 0 분에 $20 \% \mathrm{~B}$ 버퍼, 8 분에 $45 \% \mathrm{~B}$ 버퍼, 15 분에 $70 \% \mathrm{~B}$ 버퍼, 17 분에 20 분까지 $90 \% \mathrm{~B}$ 버퍼, 20.1 분에 $12 \mathrm{~B}$ 버퍼, 25 분에 $20 \% \mathrm{~B}$ 버퍼의 조건을 이용하였다.

\section{결과 및 고찰}

\section{Quercetin으로부터 isorhamnetin 3-O-glucoside생합성}

Isorhamnetin 3-O-glucoside는 Tetraena aegyptia, Salsola oppositifolia, Salicornia herbacea, Sambucus ebulus로부터 추출되며 항염, 항궤양, 2형 당뇨합병증 등의 생리효과를 가지는 flavonol 그룹 에 속하는 물질이다. Quercetin으로부터 isorhamnetin 3-Oglucoside를 생합성 하기 위해서는 flavonoid $O$-methyltransferase 와 isorhamnetin 3-O-glycosyltransferase가 필요하다(Fig. 1). 이 전의 연구결과에 의하면, flavonol의 3 번 위치에 특이적으로 당 을 붙이는 당전이 유전자들이 많이 보고되었다[6,22]. 하지만, 당전이 유전자 대부분은 quercetin과 isorhamnetin 양쪽 모두에 당을 부착하는 특성을 보이지만, 대부분의 flavonoid OMT는 당 이 부착된 물질을 기질로 사용하지 못하는 특성을 보였다[6]. 따라서 quercetin을 isorhamnetin 3-O-glucoside로 생물전환하기 위해서는 quercetin의 $3^{\prime}$ 위치에 methylation이 되어 isorhamnetin 이 생성되고 다시 이 물질의 3번 위치에 순차적으로 glycosylation 이 일어나야 한다. 이전의 연구에 의하면 포플러에서 분리한 당 전이 유전자의 돌연변이체가 isorhamnetin의 3번 위치에 특이적 으로 당을 부착하는 것으로 보고되었다[23]. 따라서 본 연구에 서는 벼에서 분리한 ROMT-9와 포플러 당전이 유전자의 돌연 변이체 PGT-3M (PGT-3 Glu82Leu)를 quercetin에서 isorhamnetin 3-O-glucoside의 생합성에 사용하였다(Fig. 1). 각 유전자가 도입 된 균주를 BL-OMT, BL-PGTM으로 명명하였다. BL-OMT, BL-PGTM균주를 이용하여 quercetin으로부터 isorhamnetin 3-Oglucoside의 생합성 가능성을 알아보기 위해 $2 \mathrm{~mL} \mathrm{LB}$ 배지에 각 각의 균주를 배양하여 $25^{\circ} \mathrm{C}$ 에서 20 시간 동안 각각의 재조합 


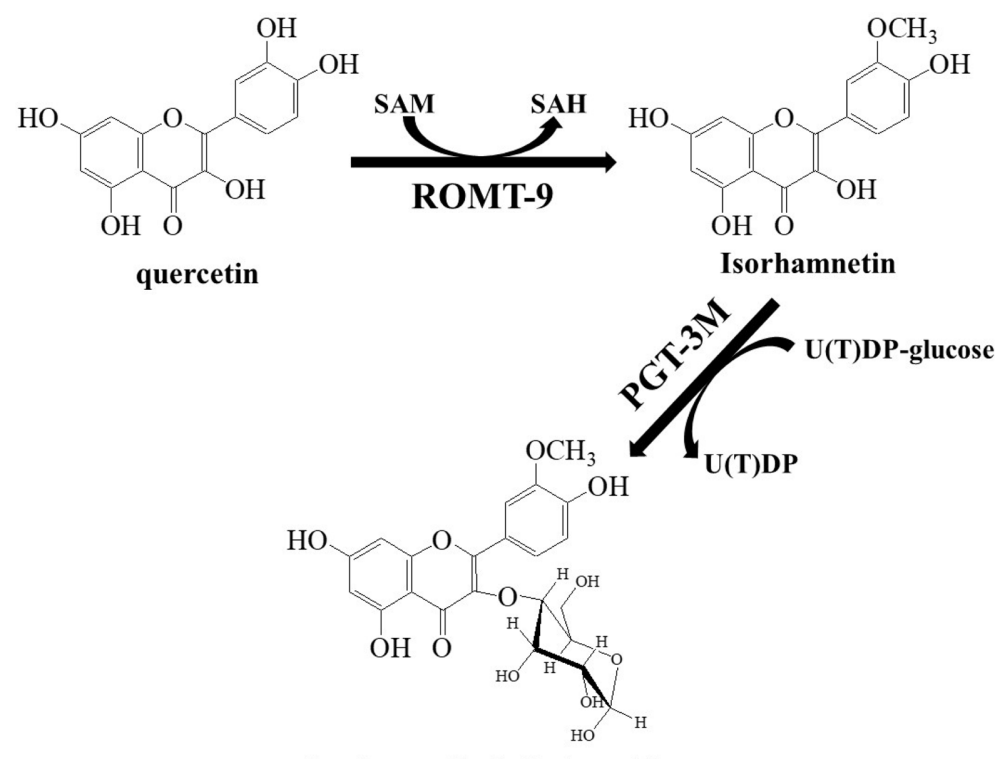

Isorhamnetin-3-O-glucoside

Fig. 1 Biosynthetic pathway of isorhamnetin 3-O-glucoside from quercetin. ROMT-9, O-methyltransferase-9 from Oryza sativa; PGTM, flavonol glycosyltransferase Glu82Leu mutant from Populus deltoids; SAM, S-adenosyl-L-methionine; SAH, S-adenosyl-L-homocysteine; U(T)DP-glucose, uridine(thymidine) diphosphate glucose

\section{(A)}

(B)

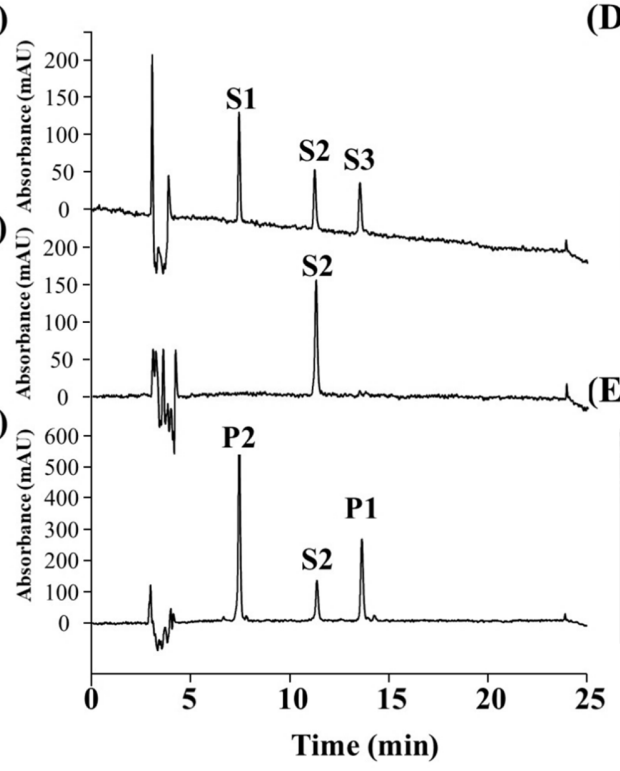

(D)

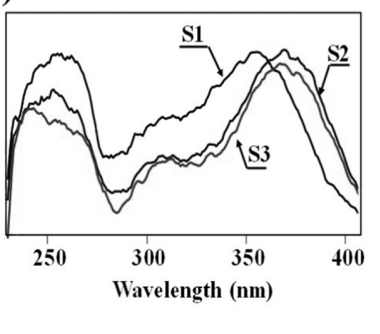

(E)

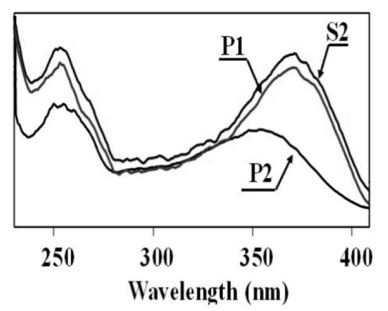

Fig. 2 HPLC analysis of biosynthesis of isorhamnetin 3-O-glucoside from quercetin. (A) HPLC chromatogram of authentic compounds, isorhamnetin 3-O-glucosie(S1), quercetin (S2), and isorhamnetin (S3); (B) HPLC chromatogram of E. coli BL21 (DE3) containing pGEX 5X-3 vector only; (C) HPLC chromatogram of the reaction products. P1 was identified to be isorhamnetin by comparing with retention time and UV spectra to standard isorhamnetin. $\mathrm{P} 2$ was identified to be isorhamnetin 3-O-glucoside by comparing retention time and UV spectra with standard isorhamnetin 3-Oglucoside; (D) UV spectra of standard isorhamnetin 3-O-glucoside (S1), quercetin (S2), and isorhamnetin (S3); (E) UV spectra of reaction products, P1 and $\mathrm{P} 2$ and quercetin(S2)

단백질을 유도하였다. 그 후 각 균주의 밀도를 동일하게 $\mathrm{AMM}$ 배지에 현탁 하여 $30^{\circ} \mathrm{C}$ 배양기에서 생물전환을 하였다. 배양 12 시간 후에 반응액을 에칠아세테이트로 추출하여 HPLC분석을 하였다. 대조구로 사용된 균주의 생물전환 결과(Fig. 2B)와 달 리 기질로 공급한 quercetin (11.2분)을 제외한 새로운 2개의 peak이 생성되었다(Fig. 2C). P1 (13.5분)은 표준물질 isorhamnetin 과 동일한 시간대(13.5분)와 $\mathrm{UV}$ 흡광도를 가지고 있었다(Fig. $2 \mathrm{D}, \mathrm{E})$. 따라서 P1은 isorhamnetin임을 알 수 있다. P2 (7.4분) 는 isorhamnetin 3-O-glucoside의 표준물질과 같은 시간대를 가 지고 있었다(Fig. 2). Isorhamnetin의 band I UV 최대 흡광도 


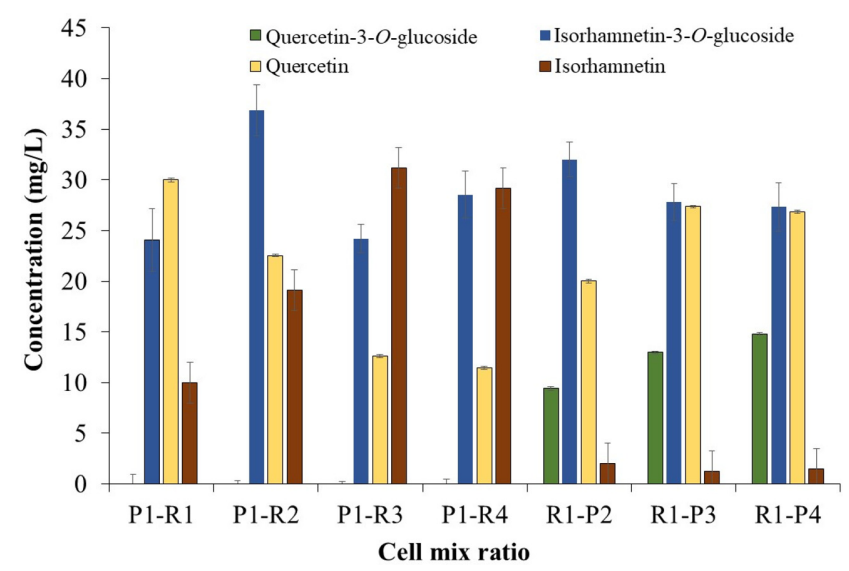

Fig. 3 Effect of biotransformation ratio on isorhamnetin 3-O-glucose production by $E$. coli co-culture. AMM supplemented with $2 \%$ glycerol was used as fermentation medium and $200 \mu \mathrm{M}$ quercetin was fed into the fermentation medium. Biotransformation was performed at $30^{\circ} \mathrm{C}$ and the reaction products were quantified by HPLC. Error bar represent mean \pm standard deviation from the three replicates

가 $365 \mathrm{~nm}$ 인데 비해 $\mathrm{P} 2$ 의 band I UV 최대 흡광도는 $353 \mathrm{~nm}$ 로 이동한 것을 보였다(Fig. 2D, E). 이와 같은 band I UV 최 대 흡광도의 이동은 isorhamnetin 3 번 탄소에 부착된 하이드록 실 그룹의 구조변화 때문에 발생하는 전형적인 hypsochromic shift 현상이다[24]. 이상의 결과는 BL-OMT와 BL-PGTM균주를 이용하여 quercetin으로부터 성공적으로 isorhamnetin 3-Oglucoside를 생성할 수 있다는 것을 의미한다.

\section{Isorhamnetin 3-O-glucoside의 생합성 최적화}

Isorhamnetin 3-O-glucoside의 생합성 최적화 방법을 탐색하기 위해 BL-OMT와 BL-PGTM균주를 동일한 비율로 섞어 25,30 , $37^{\circ} \mathrm{C}$ 에서 각각 생물전환 12 시간 후 샘플을 회수하여 분석하였 다. 생물전환온도 $25^{\circ} \mathrm{C}$ 에서 $20.9 \mathrm{mg}$ 의 isorhamnetin과 $38 \mathrm{mg}$ 의 isorhamnetin 3-O-glucoside이 생합성 되어 가장 높은 생물전환 을 보였다(Fig. S1). 다음으로 $30^{\circ} \mathrm{C}$ 로 $26.6 \mathrm{mg}$ 의 isorhamnetin과 $33.15 \mathrm{mg}$ 의 isorhamnetin 3-O-glucoside가 생산되었다. 그에 반 에 $37^{\circ} \mathrm{C}$ 에서 가장 낮은 $21.68 \mathrm{mg}$ 의 isorhamnetin 3-O-glucoside 가 생산되었지만, 다른 온도에 비해 isorhamnetin의 생산량 $(31.65 \mathrm{mg})$ 이 가장 높았다(Fig. S1). 이러한 결과는 다른 온도에 비해 $37^{\circ} \mathrm{C}$ 의 생물전환온도에서 PGT-3M의 활성이 낮은 결과에 의한 것으로 보인다. 세포 밀도가 isorhamnetin 3-O-glucoside의 생물전환에 미치는 영향을 알아보기 위하여 AMM-glucose 배 지를 기본으로 세포 비율을 $\mathrm{OD} 600 \mathrm{~nm}$ 에서 BL-PGTM와 BL$\mathrm{OMT}$ 의 비율을 2.0:2.0, 2.0:3.0, 2.0:4.0, 2.0:5.0과 BL-OMT와 BL-PGTM의 비율을 2.0:3.0, 2.0:4.0, 2,0:5.0으로 맞추어 테스트 하였다. 최적의 조합은 BL-OMT와 BL-PGTM의 세포 비율을 2.0:3.0으로 섞었을 때였으며, 이 조건에서 약 $36.85 \mathrm{mg}$ 의 isorhamnetin 3-O-glucoside가 생합성되었다(Fig. 3). BL-PGTM 의 세포보다 BL-OMT의 세포 밀도가 높아지면 isorhamnetin의 생합성이 증가하는 경향을 보였다. 하지만, BL-PGTM의 세포 밀도를 높게 하였을 때, 이전에 관찰되지 않은 새로운 물질이 관찰되었다(Fig. S2). HPLC 분석에서 이 물질은 표준물질

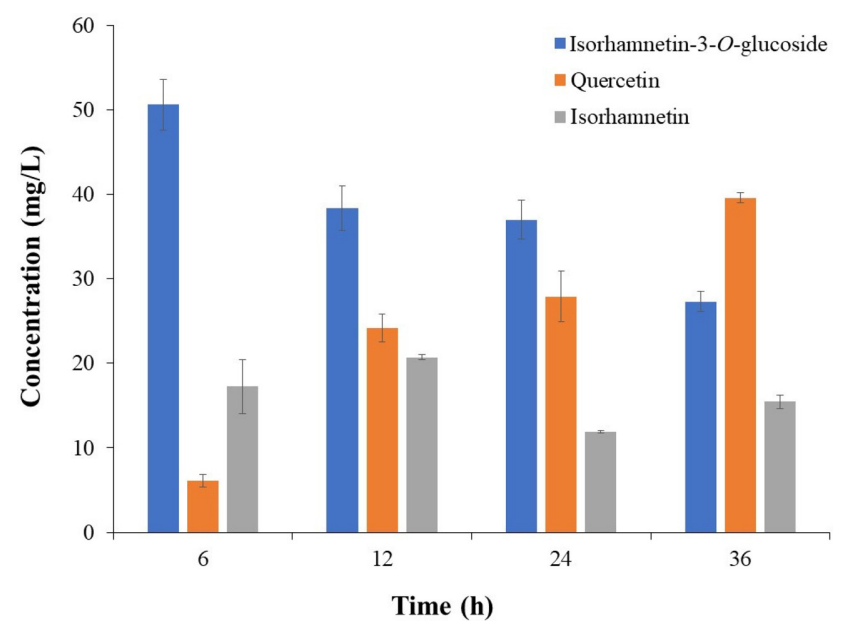

Fig. 4 Effect of IPTG induction time on isorhamnetin 3-O-glucose production by $E$. coli co-culture. The cells for recombinant protein expression were cultured for $6,12,24$, and 36 hours after IPTG addition at $25{ }^{\circ} \mathrm{C}$. The cells for biotransformation were collected at each time point by centrifugation. AMM supplemented with $2 \%$ glycerol was used as fermentation medium and $200 \mu \mathrm{M}$ quercetin was fed into the fermentation medium. Biotransformation was performed at $30^{\circ} \mathrm{C}$ and the reaction products were quantified by HPLC. Error bar represent mean \pm standard deviation from the three replicates

quercetin 3-O-glucoside와 동일한 분석시간대(6.7분)와 동일한 흡 광도를 하고 있어 quercetin 3-O-glucoside로 추정되었다(Fig. $\mathrm{S} 2)$. 이러한 결과는 BL-PGTM이 isorhamnetin보다 낮지만, quercetin에 대해서도 기질 특이성을 가지고 있다는 것을 알 수 있다. 이상의 결과로 보아 PGTM의 세포보다 ROMT-9의 세포 비율이 높아야 한다는 것을 의미한다. 재조합 단백질의 유도시 간이 isorhamnetin 3-O-glucoside에 미치는 영향을 알아보기 위 하여, ITPG추가 후 $6,12,24,36$ 시간 후에 생물전환을 하였다. 6 시간 단백질을 유도한 후 생물전환을 하였을 때 가장 높은 $50.6 \mathrm{mg}$ 의 isorhamnetin 3-O-glucoside가 생산되었다. 다음으로 12,24 시간으로 각각 $38.3,36.9 \mathrm{mg}$ 이었고, 36 시간동안 단백질 을 유도한 후 생물전환을 하였을 때 $27.3 \mathrm{mg}$ 으로 가장 낮은 생 합성을 보였다(Fig. 4). 재조합 단백질의 유도시간이 길어지면 재조합 단백질의 inclusion body 형성이 높아져 생물전환율이 줄어드는 것으로 보인다. Quercetin으로부터 isorhamnetin 3-Oglucoside의 생물전환에 미치는 배지의 영향을 알아보기 위하여 5 개의 배지(YPD, TB, AAM-glucose, AAM-glycerol, LB)를 테스트하였다. AAM-glycerol배지를 사용하였을 때 가장 높은 $52.8 \mathrm{mg}$ 의 isorhamnetin 3-O-glucoside이 생합성되었다. 다음으 로 AMM-glucose $(35.3 \mathrm{mg}), \mathrm{LB}(34.8 \mathrm{mg})$ 이었고 $\mathrm{YPD}$ 배지에 서 $12.4 \mathrm{mg}$ 으로 생합성이 가장 낮았다(Fig. 5). Quercetin의 공 급농도가 isorhamnetin 3-O-glucoside의 생합성에 미치는 영향을 알아보기 위하여, AMM-glycerol배지에 BL-OMT와 BL-PGTM 의 세포 밀도를 $\mathrm{OD} 600 \mathrm{~nm}$ 에서 2.0:3.0으로 맞춘 후 서로 다른 5 개의 농도 $(200,300,400,500,600 \mu \mathrm{M})$ 의 quercetin을 공급하 였다. $500 \mu \mathrm{M}$ 의 quercetin을 공급하였을 때 가장 많은 양의 isorhamnetin 3-O-glucoside $(180 \mathrm{mg}$ )가 생산됐지만, $600 \mu \mathrm{M}$ 이 상의 농도에서는 isorhamnetin 3-O-glucoside의 생산량이 감소하 


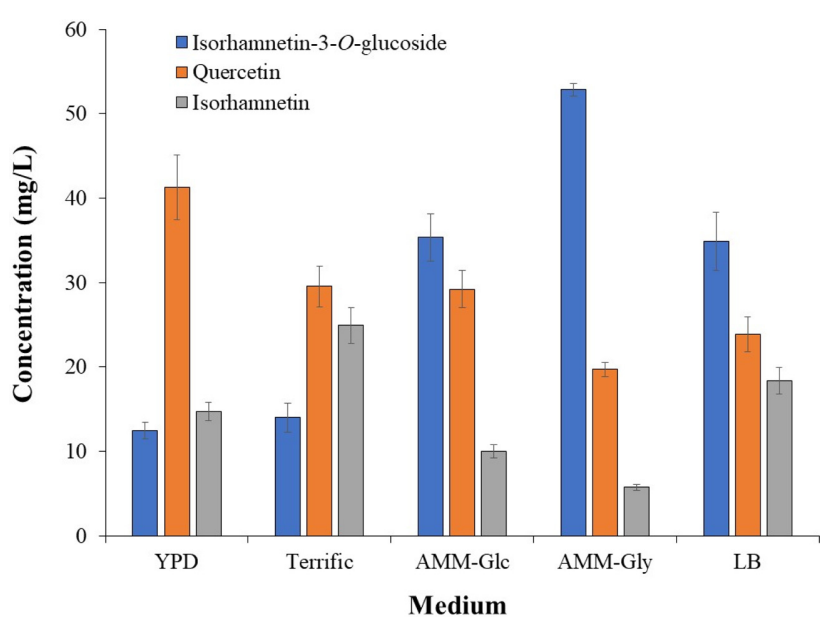

Fig. 5 Effect of biotransformation medium on isorhamnetin 3-O-glucose production by E. coli co-culture. The cells were induced at $25^{\circ} \mathrm{C}$ for 6 hours. Biotransformation was performed at $30{ }^{\circ} \mathrm{C}$ and the reaction products were quantified by HPLC. Error bar represent mean \pm standard deviation from the three replicates

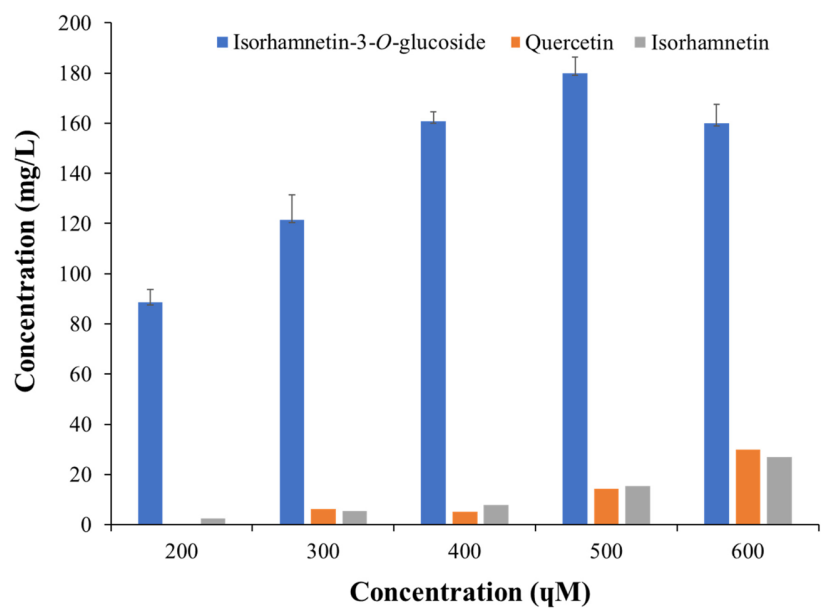

Fig. 6 Effect of quercetin feed concentration on isorhamnetin 3-Oglucose production by $E$. coli co-culture. The cells were induced at $25^{\circ} \mathrm{C}$ for 6 hours. Biotransformation was performed at $30^{\circ} \mathrm{C}$ and the reaction products were quantified by HPLC. Error bar represent mean \pm standard deviation from the three replicates

는 경향을 보였다(Fig. 6). 이러한 결과는 quercetin이 가지는 항 균효과에 의해 기인하는 현상으로 보인다.

이상의 결과를 종합해 보면 quercetin으로부터 isorhamnetin을 생합성 하기 위한 최적의 조건은 AAM-glycero배지, 재조합 단 백질 유도시간은 6시간, BL-OMT와 BL-PGTM의 세포밀도는 $\mathrm{OD} 600 \mathrm{~nm}$ 에서 2.0:3.0의 비율, quercetin $500 \mu \mathrm{M}, 25^{\circ} \mathrm{C}$ 의 생 물전환 온도였다. 이상의 조건으로 isorhamnetin 3-O-glucoside 의 생산을 48 시간 동안 관찰하였다. 배양 후 4 시간에 $32.5 \mathrm{mg}$ 의 isorhamnetin과 $144.4 \mathrm{mg}$ 의 isorhamnetin 3-O-glucoside가 생산됐지만, quercetin은 약 $25.4 \mathrm{mg}$ 이 남아 있었다. 배양의 12 시간 후 가장 많은 $181.2 \mathrm{mg}$ 의 isorhamnetin 3-O-glucoside이 생산되었고, 그 이후 isorhamnetin 3-O-glucoside의 생산량이 점

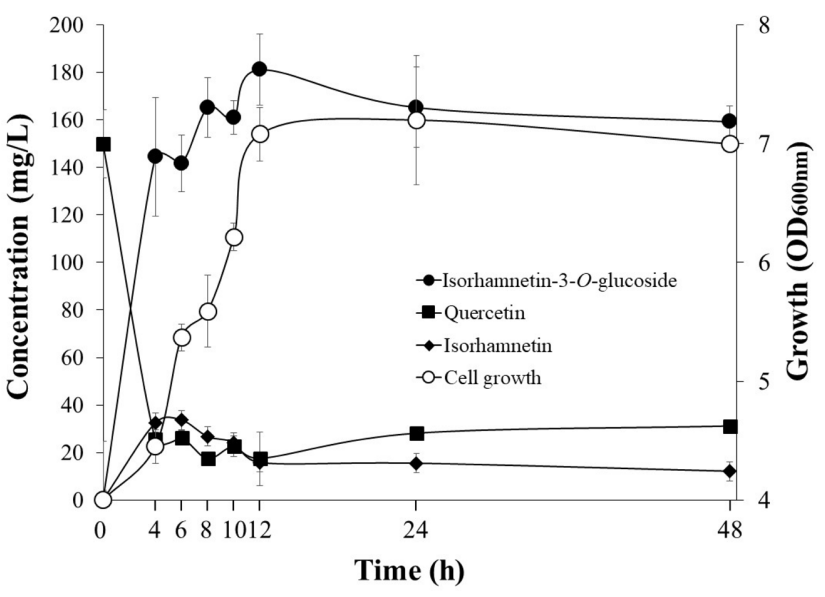

Fig. 7 Production of isorhamnetin 3-O-glucose production by E. coli coculture. AMM supplemented with $2 \%$ glycerol was used as fermentation medium. A total of $500 \mu \mathrm{M}$ quercetin was feed after induction at $25{ }^{\circ} \mathrm{C}$ for 6 hours. Biotransformation was performed at $30^{\circ} \mathrm{C}$ and the reaction products were periodically quantified by HPLC. Error bar represent mean \pm standard deviation from the three replicates

차 줄어드는 현상을 보였다(Fig. 7).

플라보노이드는 다양한 생리활성을 가지고 있어서 많은 연구 자의 관심을 받고 있다. 최근 플라보노이드를 미생물에서 간단 한 탄소원으로부터 합성하려는 연구들이 많이 시도되고 있다 $[2,25]$. 하지만, 생리활성물질을 전 합성하기 위해서는 많은 수 의 유전자를 대장균에 도입해야 한다. 또한, 반응에 필요한 다 양한 종류의 cofactor를 안정적으로 공급해야 하고, 대사정체현 상을 최소화해야 한다. 이러한 문제들 때문에 생리활성물질의 생산량을 증가시키는데 많은 어려움을 가지고 있다[26]. 이러한 문제들을 극복하기 위해 최근에 공조배양(co-culture)시스템을 이 용하여 생리활성물질을 생산하는 연구가 수행되고 있다[27,28]. 공조배양은 생합성에 관여하는 유전자들의 균주별로 분리함으 로써 생합성 경로의 대사정체(metabolic burden)현상과 부산물 의 생산을 줄일 수 있는 장점이 있다. 본 연구에서 $O$-methyltransferase (ROMT-9)와 flavonol glycosyltransferase (PGTM)을 가진 대장균 균주를 이용한 공조배양시스템으로 isorhamnetin 3$O$-glucoside 생합성 방법을 확립하였다. 확립된 공조배양시스템 으로 $500 \mu \mathrm{M}$ 의 quercetin으로부터 생물전환 12시간 후 $181.2 \mathrm{mg}$ 의 isorhamnetin 3-O-glucoside를 생합성 할 수 있었으 며, 이는 기존 대장균에서 isorhamnetin 3-O-glucoside 생산한 연구 $(39.6 \mathrm{mg})$ 보다 약 4.7 배 높았다. Isorhamnetin 3-O-glucoside 의 생산성을 높이기 위해서는 당의 공여체인 UDP-glucose와 메 칠 공여체인 $S$-adenosyl methionine (SAM)의 생합성을 증가시 키는 연구가 수행되어야 할 것으로 보인다.

\section{초 록}

Isorhamnetin 3-O-glucoside는 플라보놀 그룹에 속하는 물질로서 염증이나 궤양에 효과가 있을 뿐만 아니라 신경장해, 신장병증, 망막증과 같은 당뇨합병증을 완화하는 것으로 보고되었다. 
Isorhamnetin 3-O-glucoside는 Tetraena aegyptia, Salsola oppositifolia, Salicornia herbacea, Sambucus ebulus와 같은 몇몇 식물에서 발견된다. 생물전환은 저렴한 화합물로부터 고부가가치 물질을 생산할 수 있는 유용한 방법이다. 본 연구에서 생물전환을 통 해 quercetin으부터 isorhamnetin 3-O-glucoside를 생합성 하기 위해 두 개의 유전자(PGT E82L과, ROMT-9)를 각각의 대장균 에 도입하였다. 대장균의 공조배양시스템을 이용하여 isorhamnetin 3-O-glucoside 생산 배양법의 최적화를 위해 생물전환배지, 배 양온도, 세포의 혼합비율, 재조합 단백질 유도시간, 기질 공급 농도 등을 테스트하였다. 최적화된 생물전환 조건하에서 생물전 환을 실시하였으며, 배양의 12시간 후 $181.2 \mathrm{mg} / \mathrm{L}$ 의 isorhamnetin 3-O-glucoside가 생합성 되었다. 이는 이전의 연구에서 보고된 isorhamnetin 3-O-glucosie $(39.6 \mathrm{mg} / \mathrm{L})$ 의 생합성보다 4.7 배 높 았다.

Keywords 공조배양 - 당전이 유전자 - 생물전환 - 플라보노이 드 · $O$-메칠전이효소

감사의 글 이 논문은 경남과학기술대학교 2018-2019년도 대학회계 연구비 에 의하여 연구되었으며, 실험에 도움을 준 산림생물공학실험실 임정현, 노 혜령 학생에게 감사를 드립니다.

\section{References}

1. Terao J, Kawai Y, Murota (2008) Vegetable flavonoids and cardiovascular disease. Asia Pac J Clin Nutr 17: 291-293

2. Kim MJ, Kim BG, Ahn JH (2013) Biosynthesis of bioactive $O$ methylated flavonoids in Escherichia coli. Appl Microbiol Biotechnol 97: 7195-7204

3. Peterson J, Dwyer J (1998) Taxonomic classification helps identify flavonoid-containing foods on a semiquantitative food frequency questionnaire. J Am Diet Assoc 98: 677-682

4. Wang Y, Chen S, Yu O (2011) Metabolic engineering of flavonoids in plants and microorganisms. Appl Microbiol Biotechnol 91: 949-956

5. Kim BG, Sung SH, Chong Y, Lim Y, Ahn JH (2010) Plant flavonoid $O$ methyltransferase: substrate specificity and application. J Plant Biol 53: 321-329

6. Wang X (2009) Structure, mechanism and engineering of plant natural product glycosyltransferases. FEBS Lett 583: 3303-3309

7. María L. Falcone Ferreyra, Sebastián P. Rius, Paula Casati (2012) Flavonoids: biosynthesis, biological functions, and biotechnological applications. Front Plant Sci 3(222): 1-15

8. Graf BA, Milbury PE, Blumberg JB (2005) Flavonols, flavones, flavanones, and human health: epidemiological evidence. J Med Food 8: 281-290

9. José Justino (2017) Flavonoids: From biosynthesis of human health. InTechOpen 371-391

10. Schmidt AW, Reddy KR, Knölker HJ (2012) Occurrence, biogenesis, and synthesis of biologically active carbazole alkaloids. Chem Rev: 112: 3193-3328

11. Souza AB, Martins CH, Souza MG, Furtado NA, Heleno VC, de Sousa
JP, Rocha EM, Bastos JK, Cunha WR, Veneziani RC, Ambrósio SR (2011) Antimicrobial activity of terpenoids from Copaifera langsdorffii Desf. against cariogenic bacteria. Phytother Res 25: 215-220

12. Xiao J, Ni X, Kai G, Chen X (2013) A review on structure-activity relationship of dietary polyphenols inhibiting á-amylase. Crit Rev Food Sci Nutr 53: 497-506

13. Stachulski AV, Meng $X$ (2013) Glucuronides from metabolites to medicines: a survey of the in vivo generation, chemical synthesis and properties of glucuronides. Nat Prod Rep 30: 806-848

14. Dai J, Mumper RJ (2010) Plant phenolics: extraction, analysis and their antioxidant and anticancer properties. Molecules 15: 7313-7352

15. Xingfeng G, Daijie W, Wenjuan D, Jinhua D, Xiao W (2010) Preparative isolation and purification of four flavonoids from the petals of Nelumbo nucifera by high-speed counter-current chromatography. Phytochem Anal 21: 268-272

16. Zhou ML, Zhu XM, Shao JR, Tang YX, Wu YM (2011) Production and metabolic engineering of bioactive substances in plant hairy root culture. Appl Microbiol Biotechnol. 90: 1229-1239

17. Kim BG (2019) Biosynthesis bioactive isokaempferide from naringenin in Escherichia coli. J Appl Biol 62: 1-6

18. Han SH, Kim BG, Yoon JA, Chong Y, Ahn JH (2014) Synthesis of flavonoid $O$-pentosides by Escherichia coli through engineering of nucleotide sugar pathways and glycosyltransferase. Appl Environ Microbiol 80: 2754-2762

19. . Zaki AA, Xu X, Wang Y, Shie PH, Qiu L (2019) A new antiinflammatory flavonoid glycoside from Tetraena aegyptia. Nat Prod Res. doi: 10.1080/14786419.2019.1650356

20. Yesilada E, Gürbüz I, Toker G (2014) Anti-ulcerogenic activity and isolation of the active principles from Sambucus ebulus L. leaves. J Ethnopharmacol. 153: 478-483.

21. Jones JA, Vernacchio VR, Lachance DM, Lebovich M1, Fu L, Shirke AN, Schultz VL, Cress B, Linhardt RJ, Koffas MA (2015) ePathOptimize: A combinatorial approach for transcriptional balancing of metabolic pathways. Sci Rep 5: 11301

22. Owens DK, McIntosh CA (2009) Identification, recombinant expression, and biochemical characterization of a flavonol 3-O-glucosyltransferase clone from Citrus paradisi. Phytochemistry 70: 1382-1391

23. Kim BG, Sung SH, Jung NR, Chong Y, Ahn JH (2010) Biological synthesis of isorhamnetin 3-O-glucoside using engineered glucosyltransferase. J Mol Catal B Enzym 63:194-199

24. Kim JH, Kim BG, Park Y, Ko JH, Lim CE, Lim J, Lim Y, Ahn JH (2007) Characterization of flavonoid 7-O-glucosyltransferase from Arabidopsis thaliana. Biosci Biotechnol Biochem 70: 1471-1477

25. Cress BF, Leitz QD, Kim DC, Amore TD, Suzuki JY, Linhardt RJ, Koffas MAG (2017) CRISPRi-mediated metabolic engineering of E. coli for $O$-methylated anthocyanin production. Microb Cell Fact 16: 1-14

26. Hwang EI, Kaneko M, Ohnishi Y, Horinouchi S (2003) Production of plant-specific flavanones by Escherichia coli containing an artificial gene cluster. Appl Environ Microbiol 69: 2699-2706

27. Akdemir H, Silva A, Zha J, Zagorevski DV, Koffas MAG (2019) Production of pyranoanthocyanins using Escherichia coli co-cultures. Metab Eng 55: 290-298

28. Jones JA, Vernacchio VR, Sinkoe AL, Collins SM, Ibrahim MHA, Lachance DM, Hahn J, Koffas MAG (2016) Experimental and computational optimization of an Escherichia coli co-culture for the efficient production of flavonoids. Metab Eng 35: 55-63 